\title{
THE INFLUENCE OF TRAFFIC CONDITIONS ON THE OPERATION DISORDER OF PUBLIC TRANSPORT VEHICLES
}

\author{
Milja Simeunović, Vuk Bogdanović, Pavle Pitka, Milan Simeunović
}

Preliminary notes

In situations when in the street network there are no separate areas for the movement of public transport vehicles, traffic conditions influence their operation and efficiency. This paper studies the influence of the volume-to-capacity ratio on the disturbance of public transport headway. The research has been conducted on a segment of the roadway network, in the area of Novi Sad, on two public transport routes. The research results show that the above two parameters are in a significant correlation, that is, in case of higher volume-to-capacity ratio, disturbances in public transport operation are much more noticeable. The results also show that public transport is more prone to disturbances when public transport headways are shorter.

Keywords: headway; public transport; traffic flow; volume-to-capacity ratio

Utjecaj uvjeta odvijanja prometa na poremećaj rada vozila javnog prijevoza

Prethodno priopćenje

U situacijama kada na uličnoj mreži ne postoje izdvojene površine za kretanje vozila javnog prijevoza, uvjeti odvijanja prometa utječu na njihov rad efikasnost. U ovom radu je istraživan utjecaj odnosa zahtjeva za protokom i kapaciteta prometnica na poremećaj intervala slijeda vozila javnog prijevoza. Istraživanje je provedeno na dijelu ulične mreže, na području Novog Sada, za dvije linije javnog prijevoza. Rezultati istraživanja su pokazali da postoji značajna povezanost između ova dva parametra, kao i da su pri većem iskorištenju kapaciteta, poremećaji u radu vozila javnog prijevoza izraženiji, te da je osjetljivost na poremećaje veća za manje intervale slijeda vozila javnog prijevoza.

Ključne riječi: interval slijeda; iskorištenje kapaciteta; javni prijevoz; tok prometa

\section{Introduction}

A real traffic flow is heterogeneous and it implies various vehicle categories, wide ranging driving dynamics of the participants, and drivers with different psychophysical characteristics, ability and motivation [1]. The flow of highly heterogeneous traffic is the most common in urban environments where, in addition to various categories of motor vehicles, the structure of traffic flow often comprises bicycles, electric-powered public transport vehicles, light rail public vehicles, and the like. Additionally, traffic flow at intersections and designated pedestrian crossings interacts with pedestrian traffic flow.

The bus subsystem is the most common type of surface public transport, because it is available in all urban environments, regardless of the size of the city and its finances [2]. The buses operating in heterogeneous traffic flow regularly face the problem of their service becoming less reliable and of lower quality. Regular functioning of public passenger transport service by bus depends on many factors, such as bus stop design and capacity, day characteristics, time of the day, bus operation characteristics and traffic flow characteristics. In situations where there are no designated lanes for the movement of the buses, they operate along the roadway network, under the conditions prevailing in heterogeneous traffic flow. The heterogeneous traffic flow is the regime in which the vehicles move, it has a significant impact on bus speed, but also on headway maintenance between two successive vehicles [3]. In many world cities, traffic congestion and sporadic stoppages within the roadway network are commonplace. They often result in low reliability and quality of public bus transport service which make this type of public transport less attractive for the passengers who became less interested in using it.

In traffic flow, all the participating vehicles interact with each other, and the level of their interaction directly results from the size of traffic demand, complexity, specificity and imbalanced distribution of traffic flow on the roadway network over a time interval. When the level of vehicle interaction changes, both the size of the traffic flow parameters and the relation between them also change. This paper investigates the influence of the changed traffic flow parameters and the indicators of the traffic flow conditions onto the change of the parameters of public passenger transport service by bus. The study focuses on two bus routes of public passenger transport service, which have different vehicle headways, and which represent a segment of the Novi Sad roadway network.

\section{Literature review}

When analysing the research conducted so far, one may draw out a conclusion that a significant number of authors have studied the traffic flow conditions in heterogeneous traffic flow, and the operation of public transport vehicles in such heterogeneous traffic flow. In doing so, one group of the researchers favoured public transport, and in their respective papers they investigated the influence of the traffic flow characteristics onto the public transport bus subsystem, while some of the authors dealt with the negative influence of public transport bus service onto other participants in the traffic flow.

Thus, for example, a group of authors [4] studied in their papers the influence of parameters of traffic flow onto bus speed and the increase of bus travel time. The fundamental approach of this research is to develop a regression model that evaluates public bus travel time as a function of average travel time in traffic flow. The variables taken into account for model creating are BTT (bus travel time), as the independent variable and the dependent variables:

- $\quad D$ - distance (segment length) 
- $\quad C T T$ - car travel time

- $\quad B S$ - bus stops

- Ons - the number of passengers that boarded

- Offs - the number of passengers that alighted

- $\quad L T$ - number of left turns that the bus makes in the route segment

- $\quad$ Sig - number of traffic signals in the route segment

- Bus speed

- Car speed.

The best obtained model during bus travelling comprises the following variables:

$$
B T T=0,52+0,73 \cdot C T T+0,06 \cdot \text { Ons }+0,31 \cdot B S
$$
is 0,62 .

The determination coefficient for the obtained model

The research has shown that the difference between bus speed and light motor vehicle speed in traffic flow increases when traffic volume increases. Thus, each improvement in traffic flow operation affects the improvement in bus operation. If, for example, the car velocity is increased for $8 \mathrm{~km} / \mathrm{h}$, while the number of passengers and bus stops per one kilometre remains constantly the same, the bus velocity will increase from $17,7 \mathrm{~km} / \mathrm{h}$ to $21 \mathrm{~km} / \mathrm{h}$. It corresponds to the time saving of approximately $1 \mathrm{~min} / \mathrm{km}$, or, observing the travelling distance of $10 \mathrm{~km}$, the time saving would be about 10 minutes. In their paper, Pye and Bodé [5] presented a study conducted for the purpose of optimising the use of the existing traffic lanes designated to the operation of the buses. They analysed urban street with seven traffic signal-controlled intersections and four traffic signalcontrolled pedestrian crossings along the section. By using the traffic simulation model VISSIM, they modelled various road scenarios and identified the factors that impact bus travel time. One of these factors is traffic volume. It has determined that with the increase of traffic load, there is the increase in bus travelling time, whereby its sudden increase is noticeable for the over saturated flow. On the other hand, there is a whole range of scientific papers which study the influence of public transport bus service on other vehicles in heterogeneous traffic flow. Xiaobao and Mei [6, 7], along with some other authors, conducted a study that resulted in a number of papers investigating the influence of buses pulling up at bus stops, in order to enable alighting or to board passengers, but also the influence of the type of a bus stop onto the movement of the vehicles in heterogeneous traffic flow. The following data were used for the analysis: volume, vehicle category, travelling time of each vehicle passing the zone of the bus stop, retention time caused by bus's entering traffic flow. Research results have shown that for different traffic loads the influences of certain types of bus stops on traffic flow functions were different. For different types of bus stops, at car volumes below approximately $200 \mathrm{veh} / \mathrm{h}$, there is no significant difference in the car capacities or speeds for various stop designs. For car volumes above $200 \mathrm{veh} / \mathrm{h}$, the car capacities and speeds for the bus bay and bicycle detour designs are obviously greater than those for the curbside design. As traffic volume increases, the benefit firstly increases in uncongested conditions and then decreases in congested conditions. For car volumes above $600 \mathrm{veh} / \mathrm{h}$, both car capacities and speeds for the bicycle detour design are slightly larger than those for the bus bay design. Generally, it has been established that the consequences of bus stopping at bus stops are the decrease of roadway capacity and the increase of bus travel time. Similarly, the study of the impact of bus stops onto the decrease of roadway capacity has also been presented in the papers $[8,9]$. The authors of the paper [9] have concluded that bus stops marking on the roadway, that is, bus stopping on the traffic lane, causes the capacity loss of $23,4 \%$, as well as the occurrence of the shock way.

There are many papers dealing with the issues of public transport system functioning in heterogeneous traffic flow. They show that there is an interaction between the public transport bus subsystem and other vehicles participating in heterogeneous traffic flow.

\section{Research methodology}

For the purpose of this paper, the data from the study of public transport system and the study of the traffic flow characteristics have been used. Both studies have been conducted in the area of Novi Sad with the objective to develop the NOSTRAM Novi Sad transportation model $[10,11]$.

The research conducted within the public transport system was aimed at creating an elementary, reliable and comprehensive information base on the transportation service market, but also for the purpose of strategic and operational management of public passenger transport service in Novi Sad. Within this research, which included the count of public transport customers who were also submitted a questionnaire, the characteristics of these customers and their travel routines have also been studied, along with their requirements, public transport service offer, and the quality of public transport service on all urban and suburban routes. For the purpose of passenger counting, we have hired 1200 counters who were deployed on the buses according to the previously defined time-schedule. For each of the existing bus route, passenger counting forms were created in advance, with the code and the name of each bus stop taken from the Novi Sad Public City Transport Enterprise's distance calculator. The counters have been deployed in accordance with the bus garage numbers, for each particular bus route, and in accordance with the timeschedule of the Bus Despatch Department. The counters were recording the alighting and passengers boarding, and lap times of the buses at each bus stop.

In order to develop the NOSTRAM transport model, characteristics of traffic flow at 61 intersections on the territory of the city were counted and analysed. Also, the speed of traffic flow was measured on the primary and one segment of the secondary roadway network. Traffic count has been performed continuously, during the whole day, in 15-minute intervals, and according to the traffic flow structure.

In this paper, analysis of the influence of the traffic flow conditions onto the disturbance of public transport vehicles operation has been made using the regression analysis. The regression analysis falls into the group of 
analytical methods used to establish functional dependence between two or more variables, that is, for establishing the functional dependence between a series of random variables $Y_{1}, \ldots, Y_{n}$, and an independent variable $x$. The conclusions are drawn based on a series of paired measurements $\left(x_{1}, y_{1}\right), \ldots,\left(x_{n}, y_{n}\right)$, where $x_{1}, \ldots, x_{n}$ are values of the independent variable $x$, and $y_{1}, \ldots, y_{n}$ are respective values of the random variables $Y_{1}, \ldots, Y_{n}$. The first step in establishing the correlation between the variables $Y$ and $x$ is to draw a diagram as a form of data representation, which will clearly show whether the correlation between the variables should be described using a linear or non-linear function (polynominal function $(n \geq 2)$, a logarithmic function, etc.) [12].

Statistical check-up of the obtained correlation level between chosen variables has been performed using the MINITAB 17 application. Different tests were used for statistical evaluation of the regression model: correlation coefficient $(r)$, coefficient of determination $\left(R^{2}\right)$ and $\mathrm{p}$ value. Different authors give different interpretations of the value of the correlation that is used to determine connections, i.e. links among parameters. According to Petz [13], rough approximation of the level of correlation, it is the correlation coefficient, shows that the values in the scope between 0,00 and $\pm 0,20$ indicate no or insignificant correlation; values in the scope between \pm 0,20 and $\pm 0,40$ indicate slight correlation; values in the scope between $\pm 0,4$ and $\pm 0,7$ indicate real and significant correlation; and the values in the scope between $\pm 0,7$ and \pm 1 indicate high or very high correlation. The $p$ value underlines the significance of regression between the variables, where the values lower than 0,05 indicate that the surveyed variables are correlated, in other words, it proves that they are interdependent.

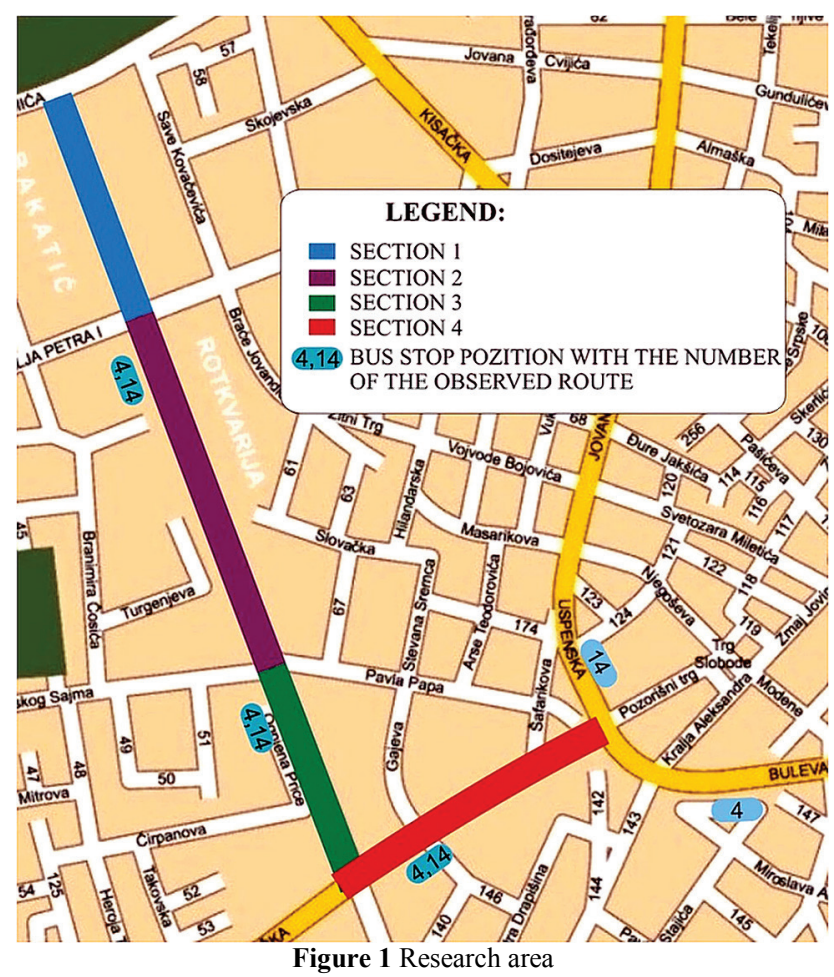

\subsection{Research area}

For the purpose of this paper, Bulevar oslobodjenja (Liberation Boulevard) and Jevrejska ulica (Jewish Street) were taken as two segments of the roadway network. Bulevar oslobođenja is the segment of the primary roadway network. It represents one of the most significant roadways in Novi Sad with the heaviest traffic load in the city. The importance of this roadway is backed up with the fact that the whole boulevard, with its studied sections, homes some thirty urban and suburban public transport routes. Jevrejska ulica leads to downtown Novi Sad, making it one of the most bustling roadways in the city, as well. For the purpose of this paper, four sections of these two roadway segments were designated. The first three sections belong to Bulevar oslobodenja, and the fourth one is Jevrejska ulica (Fig. 1). Time frame in which the data for this research were collected and which is in the focus of this paper is between 6:00 a.m. and 8:00 p.m.

\subsection{Selection of parameters for analysis}

To analyse the traffic flow conditions on the roadway network, three fundamental traffic flow parameters are most significant: volume, speed and density of traffic flow. With regard to that, traffic volume is important in the analysis of uninterrupted and sporadically interrupted traffic flows [14]. Traffic speed and density of traffic flow are important in the reach of uninterrupted traffic flows on suburban roadways. Keeping in mind that in urban environments vehicles move under interrupted traffic flow conditions, for the purpose of this study the research was focused on traffic volume, and the relation between traffic volume and the capacity of the studied segment of the roadway network. The volume values themselves are not a sufficient indicator for establishing the actual traffic flow conditions, they should rather be put in relation with roadway capacity to obtain volume-to-capacity ratio. In its essence, the volume-to-capacity ratio is the ability of the road to accommodate the level of traffic demand, it reflects the quality of the traffic flow conditions on the studied segment of the roadway network, and it is calculated as follows:

$$
X_{i}=\left(\frac{v}{c}\right)_{i},
$$

where: $v$ - volume $(\mathrm{pc} / \mathrm{h}) ; c$ - capacity $(\mathrm{pc} / \mathrm{h}) ; X_{i}-(v / c)_{I}-$ volume-to-capacity ratio for a group of traffic lanes.

The values of the volume-to-capacity ratio approaching zero indicate almost free flowing, whereas the values close to 1 indicate that volume values are approaching capacity.

The traffic volume values have been taken from the research $[10,11]$, whereas the capacity of the studied segments, depending on the specific characteristics and way of traffic regulation, has been established using the HCS software package.

The dynamic elements of the public transport vehicle operation are defined by the time-schedule, so any deviation from the planned elements of their operation 
will cause disturbances in the operation of the vehicles on public transport routes, but also in the overall public transport system [15]. Deviation from the projected values of the dynamic elements affects system reliability, and by doing so, the quality of the service rendered to the customers. For the purpose of this paper, among the existing vehicle operation elements, headway has been selected as one of the most significant dynamic elements of any transport route which reflects the quality of the transport service. Headway is defined as a time interval between two successive vehicles on the public transport route, it is a time interval between the two vehicles passing through the control point of the route [16].

Public passenger transport headway irregularity is a consequence of the headway variance of the vehicles operating along the route. Poor headway regularity of the transport vehicles has a negative effect on the following three aspects of passenger travel:

- $\quad$ extends the average passenger travel time;

- $\quad$ increases passenger travel time uncertainty;

- decreases passenger in-vehicle comfort

For the purpose of quantifying public transport vehicle headway regularity on the route studied in this paper, PRDM parametre (Percentage Regularity Deviation Mean) is used. This parametre quantifies the average deviation from the projected headway values expressed as the percentage of vehicle headway disturbance in relation to the projected headway. PRDM is used to calculate the vehicle headway regularity on a specific bus stop, but it may also be successfully used to make calculations for the whole route or some of its sections $[17,18,19]$.

$\mathrm{PRDM}_{k}=\frac{\sum_{j=1}^{n}\left|\frac{i_{p}-i_{j}}{i_{p}}\right|}{n}$,

where: $P R D M_{k}$ - percentage regularity deviation mean of headway for stop $k ; i_{j}$ - headway value for vehicle $j$ at stop $k ; i_{p}$ - projected headway value; $n$ - number of vehicles that stopped at stop $k$ during the studied time interval.

The value of PRDM parameter is determined in such a way that $0 \%$ represents perfect regularity, whereas 100 $\%$ represents a situation in which most vehicles on the route are bunching.

\subsection{Research Results}

Table 1 below shows obtained volume-to-capacity ratio values per each of the sections designated in Figure 1 in the time interval between 06:00 a.m. and 08:00 p.m., calculation based on the Eq. (2).

Table 1 Volume-to-capacity ratio on the surveyed road sections in the time interval between 06:00 a.m. and 08:00 p.m.

\begin{tabular}{|c|c|c|c|c|c|c|c|c|c|c|c|c|c|c|}
\hline \multirow{2}{*}{ Segment } & \multicolumn{14}{|c|}{ Time interval (hour) } \\
\hline & $6-7$ & $7-8$ & $8-9$ & $9-10$ & $10-11$ & $11-12$ & $12-13$ & $13-14$ & $14-15$ & $15-16$ & $16-17$ & $17-18$ & $18-19$ & $19-20$ \\
\hline 1 & 0,655 & 0,878 & 0,826 & 0,880 & 0,880 & 0,822 & 0,822 & 0,870 & 0,870 & 0,913 & 0,913 & 0,825 & 0,726 & 0,726 \\
\hline 2 & 0,503 & 0,780 & 0,803 & 0,861 & 0,861 & 0,800 & 0,800 & 0,723 & 0,723 & 0,854 & 0,884 & 0,814 & 0,683 & 0,683 \\
\hline 3 & 0,318 & 0,440 & 0,440 & 0,472 & 0,472 & 0,561 & 0,561 & 0,623 & 0,658 & 0,538 & 0,538 & 0,503 & 0,594 & 0,594 \\
\hline 4 & 0,441 & 1,019 & 0,966 & 0,889 & 0,819 & 0,892 & 0,877 & 0,877 & 0,75 & 0,907 & 0,728 & 0,642 & 0,698 & 0,698 \\
\hline
\end{tabular}

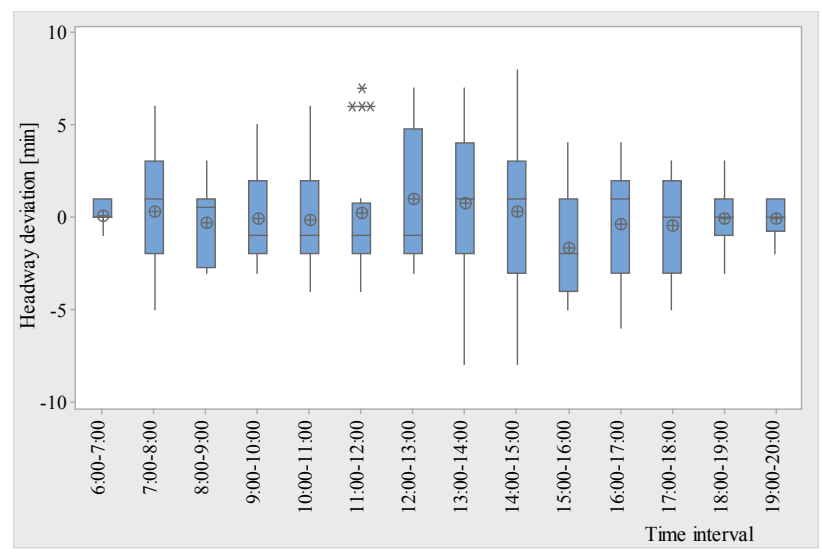

Figure 2 Deviation from the projected headway values for the bus route

Public transport vehicle headway is calculated using vehicle lap times at the surveyed bus stops recorded during the survey. A total of 324 headways on the bus route 4 , and 164 headways on the bus route 14 were selected. Headway projected values vary depending on the time of the day, and for the bus route 4, it is 9 minutes during peak hours, and 10 and 11 minutes in non-peak hours, for the surveyed time interval, whereas for the bus route 14 , the headway value is 20 minutes between 07:00 a.m. to 07:00 p.m., and for the remaining two hours that were surveyed, the value is 23 or 27 minutes. The measured headway values show that out of the total number of surveyed headways, only $15,2 \%$ of them met the projected values, and the deviation from the projected values amounted up to 15 minutes.

Figs. 2 and 3 show the deviations from the projected headway values per each hour of the surveyed time interval, for each surveyed bus route.

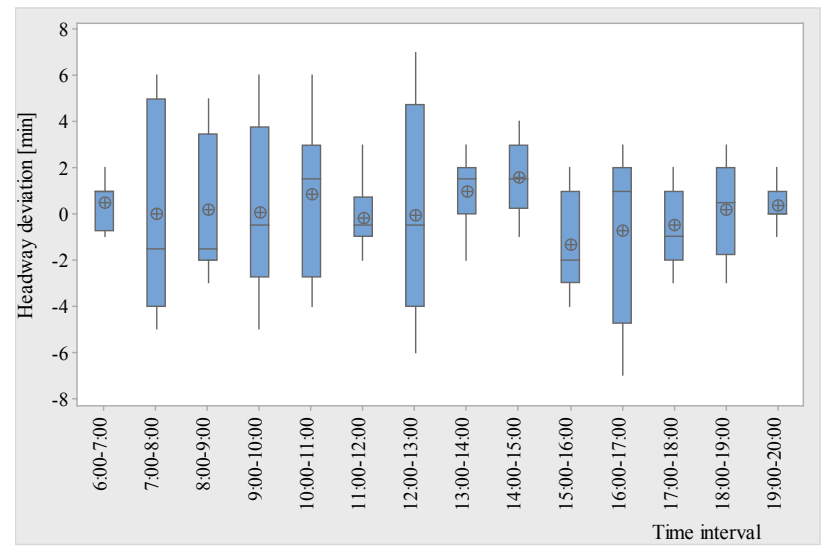

Figure 3 Deviation from the projected headway values for the bus route 14 
Values of PRDM factor, calculation based on the Eq. (3), for the vehicles on the bus route 4 and the bus route 14, are shown in Tab. 2.

\subsection{Analysis of research results}

Analysis of the influence of the traffic flow conditions onto the disturbance of public transport vehicle operation has been made based on the relation between the volume-to-capacity ratio value and $P R D M$ parameter value, using the regression analysis.

Based on the established relation between the volume-to-capacity ratio and PRDM parameter for each of the surveyed sections, it has been concluded that their correlation is best described by the second degree polynomial function. Some of the extreme PRDM values obtained during the survey have been excluded from the analysis, and these values are highlighted in yellow in Tab. 2. The graphs are provided below.

Table 2 Overview of PRDM parameter values

\begin{tabular}{|c|c|c|c|c|c|c|c|c|c|c|c|c|c|c|c|}
\hline \multirow{2}{*}{\multicolumn{2}{|c|}{ Segment }} & \multicolumn{14}{|c|}{ Time interval (hour) } \\
\hline & & $6-7$ & $7-8$ & $8-9$ & $9-10$ & $10-11$ & $11-12$ & $12-13$ & $13-14$ & $14-15$ & $15-16$ & $16-17$ & $17-18$ & $18-19$ & $19-20$ \\
\hline \multirow{4}{*}{$\begin{array}{l}+ \\
0 \\
\stackrel{\Xi}{*} \\
\stackrel{0}{\simeq}\end{array}$} & 1 & 0,03 & 0,23 & 0,15 & 0,27 & 0,14 & 0,20 & 0,31 & 0,39 & 0,31 & 0,37 & 0,15 & 0,19 & 0,11 & 0,07 \\
\hline & 2 & 0,03 & 0,27 & 0,20 & 0,21 & 0,25 & 0,22 & 0,22 & 0,41 & 0,25 & 0,33 & 0,35 & 0,23 & 0,08 & 0,09 \\
\hline & 3 & 0,08 & 0,25 & 0,15 & 0,12 & 0,11 & 0,24 & 0,25 & 0,48 & 0,68 & 0,37 & 0,13 & 0,25 & 0,16 & 0,07 \\
\hline & 4 & 0,03 & 0,32 & 0,17 & 0,17 & 0,21 & 0,23 & 0,30 & 0,39 & 0,75 & 0,41 & 0,22 & 0,19 & 0,08 & 0,07 \\
\hline \multirow{5}{*}{ 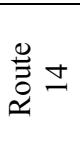 } & & & & & & & & & & & & & & & \\
\hline & 1 & 0,05 & 0,18 & 0,15 & 0,12 & 0,10 & 0,08 & 0,15 & 0,12 & 0,08 & 0,12 & 0,13 & 0,07 & 0,05 & 0,00 \\
\hline & 2 & 0,05 & 0,30 & 0,17 & 0,12 & 0,13 & 0,05 & 0,10 & 0,05 & 0,07 & 0,12 & 0,13 & 0,08 & 0,10 & 0,02 \\
\hline & 3 & 0,05 & 0,07 & 0,07 & 0,05 & 0,10 & 0,12 & 0,33 & 0,13 & 0,12 & 0,12 & 0,15 & 0,10 & 0,08 & 0,10 \\
\hline & 4 & 0,06 & 0,28 & 0,07 & 0,25 & 0,18 & 0,07 & 0,28 & 0,07 & 0,08 & 0,17 & 0,17 & 0,05 & 0,10 & 0,02 \\
\hline
\end{tabular}

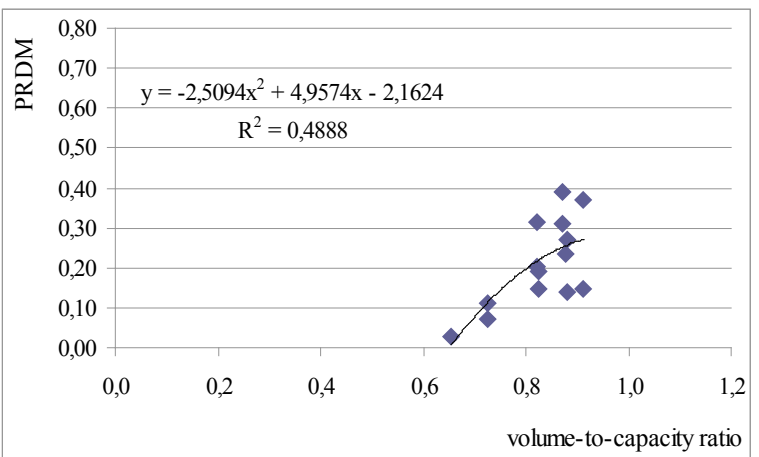

a) Segment 1

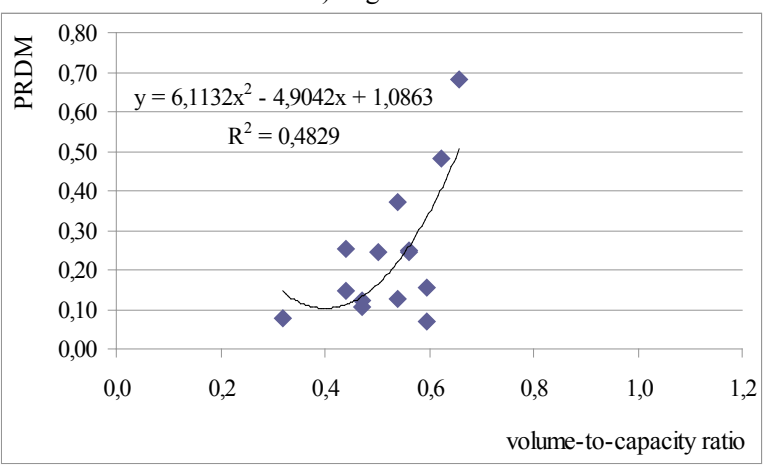

c) Segment 3

Figure 4 Correlation between volume-to-capacity and PRDM parameter for bus line 4, per each section

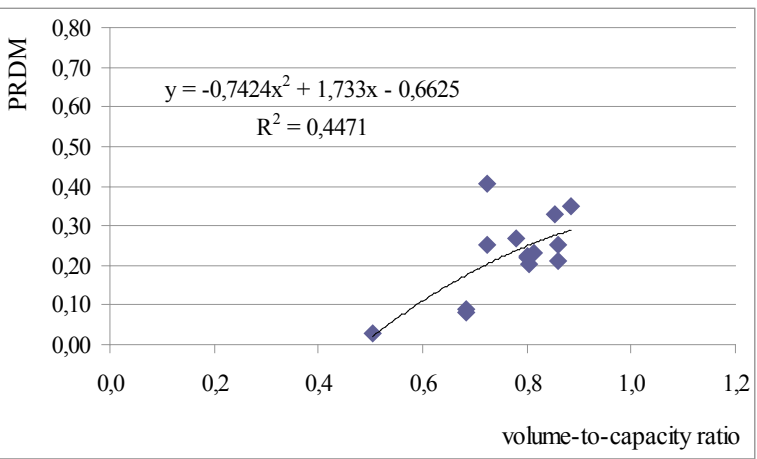

b) Segment 2

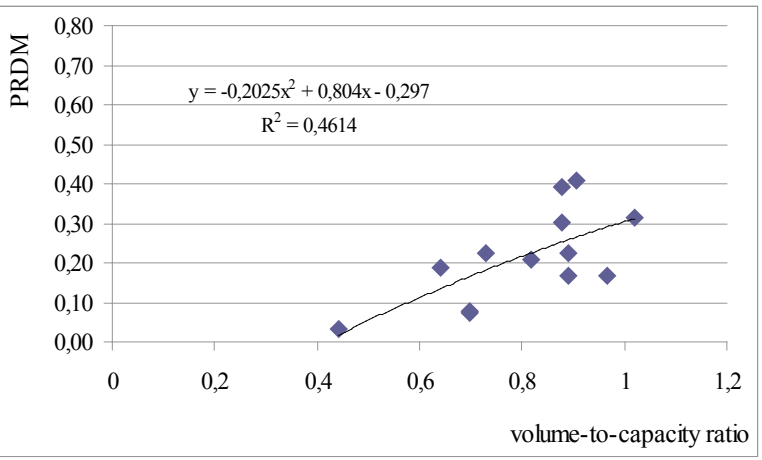

d) Segment 4
In the graphs (Fig. 4 and Fig. 5), despite a significant dispersion between the paired values, the positive correlation trend between volume-to-capacity ratio and $P R D M$ parameter is observed. By putting these variables in correlation, a significant polynomial correlation has been noticed, as presented in the graphs above. The graphs show that when volume-to-capacity ratio increases, the value of PRDM parameter also increases. Hence, the disturbance of public transport vehicle operation is more expressed during heavy traffic conditions. The level of correlation between the two variables is determined by the correlation coefficient. The obtained correlation coefficient for the analysed variables varies from one section to another, but is has been observed that the values of the coefficients on both bus routes, on the surveyed sections, are similar. The scope of the correlation coefficient for the bus route 4 , and bus route 14 is between 0,67 and 0,70 , and between 0,68 and 0,70 , respectively.

What is interesting is the fact that on the same sections, that is for the same volume-to-capacity ratio values, significantly higher $P R D M$ parameter values were obtained on the bus route 4 , in comparison with the bus route 14. This fact may be explained by the original definition of the parameter. Namely, it represents the relative value of vehicle headway disturbance in relation 
to its projected value. In other words, the lower headway projected value, the higher disturbance sensitivity.

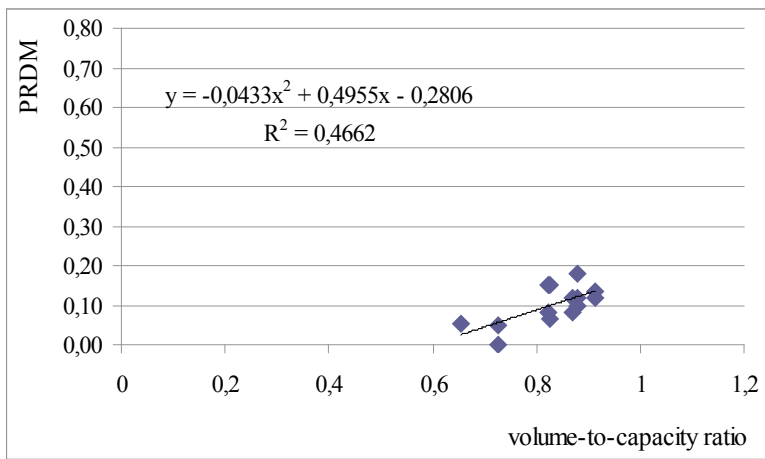

a) Segment 1

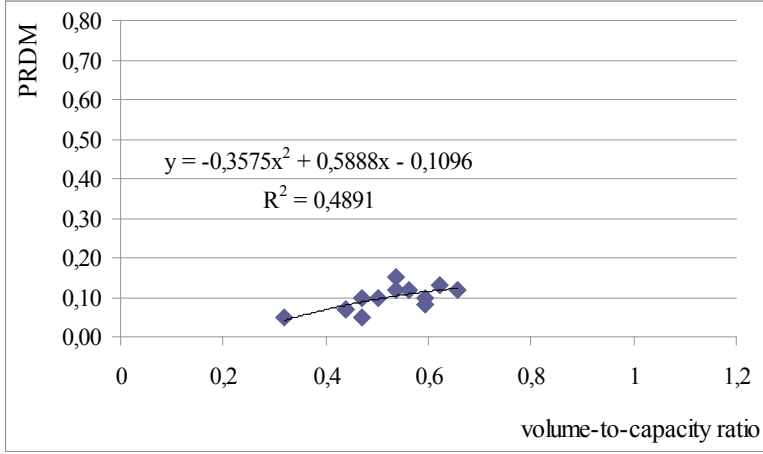

c) Segment 3

volume-to-capacity ratio

Figures 5 Correlation between volume-to-capacity and PRDM parameter for bus line 14, per each section

Table 3 Regression modelling results for line 4

\begin{tabular}{|c|c|c|c|c|c|c|c|c|}
\hline Segment & $a$ & $b$ & $c$ & $F$ & $p$ & $R^{2}$ & $r$ & Comment \\
\hline 1 & $-2,509$ & 4,957 & $-2,162$ & 5,26 & 0,025 & 0,489 & 0,70 & significant correlation \\
\hline 2 & $-0,742$ & 1,733 & $-0,663$ & 4,45 & 0,038 & 0,447 & 0,67 & significant correlation \\
\hline 3 & 6,113 & $-4,904$ & 1,086 & 5,14 & 0,027 & 0,483 & 0,69 & significant correlation \\
\hline 4 & $-0,203$ & 0,804 & $-0,297$ & 4,28 & 0,045 & 0,461 & 0,68 & significant correlation \\
\hline
\end{tabular}

Table 4 Regression modelling results for line 14

\begin{tabular}{|c|c|c|c|c|c|c|c|c|}
\hline Segment & $a$ & $b$ & $c$ & $F$ & $p$ & $R^{2}$ & $r$ & Comment \\
\hline 1 & $-0,043$ & 0,496 & $-0,281$ & 4,80 & 0,032 & 0,466 & 0,68 & significant correlation \\
\hline 2 & 0,949 & $-1,085$ & 0,355 & 4,77 & 0,035 & 0,488 & 0,70 & significant correlation \\
\hline 3 & $-0,358$ & 0,589 & $-0,110$ & 4,79 & 0,035 & 0,489 & 0,70 & significant correlation \\
\hline 4 & 0,796 & $-0,777$ & 0,239 & 4,34 & 0,044 & 0,465 & 0,68 & significant correlation \\
\hline
\end{tabular}

\section{Conclusion}

This paper investigates the influence of the traffic flow conditions onto the disturbance of public transport vehicle headways. The research of the level in which traffic flow influences headway disturbance has been conducted using real data obtained in a survey on the territory of Novi Sad. For the purpose of this paper, 4 sections have been selected as parts of Bulevar oslobođenja and Jevrejska ulica, in Novi Sad, with two bus routes, number 4 and 14. In order to investigate the influence of the traffic flow conditions onto the disturbance of public transport vehicle operation - buses, volume-to-capacity ratio of the surveyed segments of the roadway network is correlated with the PRDM parameter, which quantifies the average deviation from the projected headway. Regression analysis is applied to see the correlation between volume-to-capacity ratio and PRDM parameter. The results of the analysis show that there is a significant level of correlation between the two, and that with the increase of the volume-to-capacity ratio value, the $P R D M$ parameter value also increases, meaning that bus operation disturbance is higher. The obtained correlation coefficients indicate that the observed variable, for both surveyed public bus routes, are in real and significant correlation. Another conclusion that may be drawn based on the presented analysis is that disturbance sensitivity increases when projected headway decreases. Statistical check-up of the correlation between volume-to-capacity ratio and PRDM parameter has been performed using the MINITAB 17 application. The obtained results also confirm the correlation between the surveyed variables.

Understanding of the influence of the traffic flow conditions onto the elements of public transport vehicle operation may be successfully utilised in public transport vehicle operation planning, so as to adjust vehicle headways to various levels of service required during the 
day on the roadway network, whose relation is expressed by the volume-to-capacity ratio.

It should be noted, however, that public transport operation disturbances are also resulting from the activities carried out at bus stops and terminuses, so these influences should also be included in any future research.

\section{References}

[1] Kuzović, Lj.; Bogdanović, V. Teorija saobraćajnog toka, Fakultet tehničkih nauka, Novi Sad, 2010.

[2] Vučić, V. Javni gradski prevoz, Sistemi i tehnika, Naučna knjiga, Beograd, 1987.

[3] Suwardo, N. M.; Kamaruddin, I. On-Time Performance and Service Regularity of Stage Buses in Mixed Traffic. // World Academy of Science, Engineering and Technology International Journal of Civil, Architectural, Structural and Construction Engineering. 3, 7(2009), pp. 10-17.

[4] McKnight, C. E.; Levinson, H.; Ozbay, K.; Kamga, C.; Paaswell, R. E. Impact of traffic congestion on bus travel time in Northern New Jersey. // Transportation Research Record. 1884, (2004), pp. 27-35. DOI: 10.3141/1884-04

[5] Pye, R.; Bodé, B.; Route 149 - Intensive Bus Priority // Transportation Research Board. (2006)

[6] Yang, X.; Huan, M.; Gao, Z. Car Delay Model near Bus Stops with Mixed Traffic Flow. // Journal of Central South University, China. 19, (2013), pp. 2697-2704. DOI: 10.1007/s11771-012-1329-2

[7] Yang, X.; Si, B.; Huan, M. Mixed Traffic Flow Modelling near Chinese Bus Stops and its Applications. // Journal of Applied Mathematics. 2013 (2012)

[8] Kwami, A. V.; Kuan, Y. X.; Zhi, X. Effect of Bus Bays on Capacity of Curb Lanes. // Journal of American Science, Marsland Press. 5, 2(2009), pp 107-118.

[9] Ben-Edigbe, J.; Mashros, N. Determining Impact of BusStops on Roadway Capacity. // Proceedings of the ITRN 2011 / University College Cork, (2011)

[10] Simeunović, M.; Pitka, P.; Leković, M.; Saulić, N. Sistemsko-generalno brojanje i anketa putnika u javnom gradskom i prigradskom prevozu putnika na području Novog Sada. // Departman za saobraćaj, Fakultet tehničkih nauka, Novi Sad, 2011.

[11] Bogdanović, V.; Papić, Z.; Simeunović, M.; Leković, M. et al. Saobraćajna studija Grada Novog Sada sa dinamikom uređenja saobraćaja i izradom novosadskog transportnog modela -NOSTRAM- // Departman za saobraćaj, Fakultet tehničkih nauka, Novi Sad, 2010

[12] Regresijska analiza www.mathos.unios.hr/ptfstatistika/ .../materijali_7.pdf (25.02.2015)

[13] Petz, B. Osnovne statističke metode za nematematičare, Drugo izdanje, Sveučilišna naklada liber, Zagreb, 1985

[14] Kuzović, Lj. Kapacitet i nivo usluge drumskih saobraćajnica, Univerzitet u Beogradu, Saobraćajni fakultet, Beograd 2000.

[15] Leković, M.; Simeunović, M.; Bogdanović, V. Characteristic of moving of transit in mixed traffic flow. // International Conference on Traffic and Transport Engineering (ICTTE) / Belgrade, (2012), pp. 253-257.

[16] Banković, R. Organizacija i tehnologija javnog gradskog putničkog prevoza, Saobraćajni fakultet, Beograd, 1994.

[17] Van Oort, N. Incorporating service reliability in public transport design and performance requirements: International survey results and recommendations. // Research in Transportation Economics. (2014), pp 1-9. DOl: 10.1016/j.retrec.2014.09.036

[18] Hakkesteegt, P.; Muller, J. H. Research increasing regularity. // Verkeerskundige werkdagen. (1981), pp. 415436
[19] Sorratini, J. A. P.; Ronghui, L.; Shalini, S. Assessing Bus Transport Reliability Using Micro-Simulation. // Transportation Planning and Technology. 31, 3(2008), pp 303-324. DOI: $10.1080 / 03081060802086512$

\section{Authors' addresses}

Milja Simeunović, PhD Candidate

Faculty of Technical Science,

University of Novi Sad,

Trg Dositeja Obradovića 6,

21000 Novi Sad, Serbia

E-mail: mlekovic@uns.ac.rs

Vuk Bogdanović, Prof. Dr

Faculty of Technical Science, University of Novi Sad,

Trg Dositeja Obradovića 6,

21000 Novi Sad, Serbia

E-mail:vuk@uns.ac.rs

Pavle Pitka, PhD Candidate

Faculty of Technical Science, University of Novi Sad,

Trg Dositeja Obradovića 6

21000 Novi Sad, Serbia

E-mail: pitka04@yahoo.com

Milan Simeunović, Prof. Dr

Faculty of Technical Science, University of Novi Sad,

Trg Dositeja Obradovića 6 ,

21000 Novi Sad, Serbia

E-mail: milansim@uns.ac.rs 